\title{
Correlation between microbial enzyme activities in the rumen fluid of sheep under different treatments
}

\author{
Ali MoHARrerY ${ }^{\mathrm{a} *}$, Tirta K. DAS ${ }^{\mathrm{b}}$ \\ a Animal Science Department, Faculty of Agriculture, Shahr-e-Kord University, \\ Shahr-e-Kord, Iran \\ b Animal Nutrition Department, Veterinary College, University of Agricultural Sciences, \\ Bangalore 560 024, India
}

(Received 4 May 2001; accepted 17 December 2001)

\begin{abstract}
Five total mixed rations prepared from finger millet (Eleusine Coracana) straw as a roughage $(48 \%)$ and mixed concentrate $(52 \%)$, supplemented with a $1 \%$ isoacid mixture $\left(\mathrm{i}-\mathrm{C}_{4}\right.$, $\mathrm{i}-\mathrm{C}_{5}, \mathrm{C}_{5}$ and phenylacetic acid in equal proportions) or oil (groundnut oil, $5 \%$ more than the control) or urea (5\% more nitrogen than the control), and protein (groundnut cake, $5 \%$ more nitrogen than the control) were given in a Latin square experiment to sheep. Enzymatic activities were estimated for urease, cellulase, protease, amylase, and lipase in various fractions of rumen fluid on the one hand and rumen microbial biomass on the other hand. Rumen samples were taken 3-4 hours after feeding and mixed rumen bacteria were separated as a strained rumen fluid without protozoa (SRFWP), cell free rumen fluid (CFRF) and enzymes associated with the bacteria cell (EABC). Samples of SRFWP and EABC contained higher enzyme activities than CFRF. Depending on the type of enzymes in each fraction, some significant coefficient of determination $\left(r^{2}\right)$ was seen. These values showed very close cooperative action between proteolytic and amylolytic enzymes under the experimental conditions, or perhaps the presence of some species of bacteria with both activities. Lipolytic bacteria are completely specialized for lipase production only $(P<0.05)$. The results showed oil, isoacid and crude protein enhanced microbial production $(P<0.05)$ and this can change the pattern of enzymes in the rumen of sheep.
\end{abstract}

isoacid / urease / cellulase / protease / amylase / lipase / sheep / rumen

\footnotetext{
* Correspondence and reprints

E-mail: moharrery@yahoo.com
} 


\section{INTRODUCTION}

The ruminal microbes include a large variety of bacterial, protozoal and fungal species making the rumen habitat very complex. Numerous interactions have been observed between these largest groups of microorganisms that exist in the rumen [17]. These microbes, through their enzymes [50], play roles in digestive processes. Complete digestion of complex feeds such as hay or grain literally requires hundreds of enzymes [42]. In microbial terms, the enzyme activity is not particularly high; it is the high microbial biomass and long residence time of feed material in the digesta that causes the high extent of breakdown of susceptible material [46]. Considerable progress has been made towards the development of quantitative relationships among the chemical composition of ruminant feeds, dynamic aspects of digestion in the rumen, products of digestion absorbed by the ruminant, and, most important, how these can be manipulated to improve animal productivity. The establishment and maintenance of a stable population is dependent on the diet, level of feeding, frequency of feeding and microbial interactions [19]. Even within a single microbial species, the types and activities of enzymes produced can vary widely, depending on the strain selected and the growth substrate and culture conditions employed [14, 23].

It has been recognized for some time that urea may be used to replace a portion of the protein in the rations of ruminant animals [54]. The branched-chain fatty acids (isoacid) isobutyric (i- $\left.\mathrm{C}_{4}\right), 2$-methylbutyric $\left(2 \mathrm{Me}-\mathrm{C}_{4}\right)$ and isovaleric $\left(\mathrm{i}-\mathrm{C}_{5}\right)$ and the straight-chain valeric acid $\left(n-C_{5}\right)$ are naturally produced in the digestive tract of the ruminant [2] and rumen microorganisms can convert isoacids to amino acids. Stack et al. [61] indicated that the cellulolytic rumen bacterium, $R$. albus, has a requirement for phenylacetic acid. Use of phenylacetic acid as a branched-chain fatty acid has been reported by Hefner et al. [28]. The use of isoacid [10, 20, 43, 60] is coupled with microbial growth, which also needs $\mathrm{NH}_{3}$ as a component for protein synthesis. Lipids can also be used to manipulate the digestion and absorption of different nutrients [32, 34, 35]. The different enzyme activities that occur between types and species of organisms result in a distinct synergism and crossed feeding. In the end, this could be beneficial to the animal host through increases in digestibility and diet utilization [17].

Feed nutritive value is essentially a function of the availability of energy and needed nutrients. Rumen microorganisms have a potential for the utilization of nutrients through their activities and beside these activities, they also produce metabolites that are efficiently used by ruminants. Animal response to a feed is, therefore, dependent upon a complex interaction of the composition of the diet, its preparation and consequent nutritive value. On the contrary, dietary factors influence the rumen ecosystem, which may have positive or negative effects on microbial activity and consequently on animal production.

The objectives of the present experiment were to study the effects of isoacid, oil, urea and protein on the enzyme pattern in fractionated rumen fluid and to investigate the role of these materials on microbial activity. Since no attempt has been made in the past to characterize the correlation between the enzymes in rumen fluid, one of the objectives of this experiment was to tentatively characterize the major types of rumen fluid enzymes and determine the correlation between them.

\section{MATERIALS AND METHODS}

\subsection{Materials}

\subsubsection{Animals}

Five male sheep (native breed) between the ages of about 18 to 24 months having body weights of 23 to $26 \mathrm{~kg}(24 \pm 2.1)$ were selected for the experiment. 


\subsubsection{Fodder}

\subsubsection{Straw}

Sun dried good quality finger millet (Eleusine Coracana) straw was chopped with the help of a handchopper into a size of about five to six centimeters long. Straw formed $48 \%$ of the rations.

\subsubsection{Feed}

The ingredients used in the preparation of the total mixed ration (TMR) are shown in Table I. The experimental diets comprising a control diet, control diet plus $1 \%$ mixed isoacids ( $\mathrm{i}-\mathrm{C}_{4}, \mathrm{i}-\mathrm{C}_{5}, \mathrm{C}_{5}$ and phenylacetic acid in equal proportions) or oil (groundnut oil, $5 \%$ more ether extract than the control diet), urea diet (5\% more nitrogen from urea, than the control diet) and protein diet (5\% more nitrogen from the groundnut cake than the control diet) were given to the respective animals belonging to each diet, under a rotational form.

\subsection{Methods}

\subsubsection{Management of feeding and duration}

The amount of feed offered to each sheep during the adaptation period was

Table I. Composition of the experimental diets (\%).

\begin{tabular}{|c|c|c|c|c|c|}
\hline Ingredient & Control & Isoacid & Oil & Urea & Protein \\
\hline Finger millet straw & 48.00 & 48.00 & 48.00 & 48.00 & 48.00 \\
\hline Maize & 20.80 & 20.80 & 15.60 & 20.80 & 13.52 \\
\hline Groundnut Cake & 5.20 & 5.20 & 6.24 & 5.20 & 24.44 \\
\hline Rice bran & 13.52 & 13.52 & 11.44 & 13.52 & 3.64 \\
\hline Soybean meal & 7.28 & 7.28 & 8.32 & 5.20 & 5.20 \\
\hline Oil (Ground Nut) & - & - & 5.20 & - & - \\
\hline Urea & - & - & - & 2.057 & - \\
\hline Isoacid ${ }^{*}$ & - & 1.04 & - & - & - \\
\hline Vitamin + Mineral supplement & 1.04 & 1.04 & 1.04 & 1.04 & 1.04 \\
\hline Calcite & 1.04 & 1.04 & 1.04 & 1.04 & 1.04 \\
\hline Salt & 1.04 & - & 1.04 & 1.04 & 1.04 \\
\hline Dicalcium phosphate & 2.08 & 2.08 & 2.08 & 2.08 & 2.08 \\
\hline \multicolumn{6}{|l|}{ Composition (DM basis) } \\
\hline $\mathrm{DM}(\%)$ & 84.53 & 84.53 & 85.05 & 84.76 & 84.38 \\
\hline $\operatorname{ME}\left(\mathrm{Mcal} \cdot \mathrm{kg}^{-1}\right)^{\mathrm{a}}$ & 2.793 & 2.793 & 2.958 & 2.720 & 2.756 \\
\hline $\operatorname{TDN}(\%)^{\mathrm{a}}$ & 69.87 & 69.87 & 75.24 & 67.96 & 68.73 \\
\hline $\mathrm{CP}(\%)$ & 12.25 & 12.25 & 12.36 & 17.68 & 17.11 \\
\hline $\operatorname{DIP}(\%)^{\mathrm{a}}$ & 8.89 & 8.89 & 9.02 & 14.82 & 13.08 \\
\hline $\operatorname{UIP}(\%)^{\mathrm{a}}$ & 3.37 & 3.37 & 3.33 & 3.05 & 4.04 \\
\hline $\mathrm{EE}(\%)$ & 2.34 & 2.34 & 7.58 & 2.31 & 1.55 \\
\hline NFE (\%) & 54.29 & 54.29 & 49.47 & 53.34 & 50.02 \\
\hline $\operatorname{Ash}(\%)$ & 12.28 & 12.28 & 12.07 & 12.11 & 12.18 \\
\hline $\mathrm{CF}(\%)$ & 20.35 & 20.35 & 19.73 & 20.10 & 20.35 \\
\hline $\operatorname{ADF}(\%)$ & 26.23 & 26.33 & 25.42 & 25.91 & 26.23 \\
\hline Cellulose (\%) & 20.15 & 20.15 & 19.82 & 19.84 & 21.01 \\
\hline $\mathrm{Ca}(\%)^{\mathrm{a}}$ & 1.13 & 1.13 & 1.13 & 1.12 & 1.13 \\
\hline $\mathrm{P}(\%)^{\mathrm{a}}$ & 0.92 & 0.92 & 0.87 & 0.90 & 0.77 \\
\hline
\end{tabular}

* Isoacids included I-C4, I-C5, C5 and phenylacetic acid in equal proportions.

a From the table of nutrient requirements of sheep [47].

Only data related to finger millet straw was taken from Ranjhan [53]. 
calculated according to the animal's live weight by means of defined formula, to give a near maintenance level. In this manner, during the adaptation period each sheep consumed $520 \mathrm{~g}$ air dry TMR (total mixed ration) per day. In successive periods, the amount of feed offered was increased to $625 \mathrm{~g}$ for sheep. The diets were fed twice daily at 06.00 and 15.00 hours. Clean water was offered ad libitum after feeding for $1 / 2$ hour and water was removed to avoid any dilution of the rumen content before sampling.

The duration of each period was 15 days (10 days adaptation to each diet and 5 days for the sampling period) and after this time the ration of each sheep was replaced with another ration during another period, thus rotating to the end of the 5 periods. Each sheep consumed 5 rations in 5 periods.

\subsubsection{Sampling}

\subsubsection{Sampling of rumen contents}

In the fifteenth day of each period, rumen samples from each animal were removed via a stomach tube with the help of a vacuum pump, 3 to $4 \mathrm{~h}$ after the morning feeding. Samples $(150 \mathrm{~mL})$ were kept in an ice bath and after collection, they were transferred to the laboratory immediately. Rumen fluid was strained through four layers of cotton gauze and centrifuged once at $1000 \mathrm{~g}$ for $10 \mathrm{~min}$. The supernatant fluid was carefully decanted and divided into two parts. One part was stored at $-196{ }^{\circ} \mathrm{C}$ in liquid nitrogen for future analysis [45] and named as the strained rumen fluid without protozoa (SRFWP), another part $(25 \mathrm{~mL})$ was then centrifuged again $(26000 \mathrm{~g}, 15 \mathrm{~min})$ and the supernatant fluid was carefully decanted and stored at $-196{ }^{\circ} \mathrm{C}$ as a sample without any microbes, and named as the cell free rumen fluid (CFRF). The pellet was resuspended in buffer solution [44] and this suspension was centrifuged $(26000 \mathrm{~g}$, $10 \mathrm{~min}$ ). After decanting of the supernatant fluid, the pellet was resuspended to one fifth of the original volume in buffer solution and the cells were broken by five 60 -s periods of sonication with 60 -s intervals under an ice bath. Sonically-disrupted cells were centrifuged at $40000 \mathrm{~g}$ for $10 \mathrm{~min}$. The clear supernatant was kept at $-196{ }^{\circ} \mathrm{C}$ for future studies on enzymes and named as the enzyme associated with bacteria cell (EABC).

\subsubsection{Sampling of urine}

In the last five days from each period, the urine of each sheep was collected in a polythene bag twice daily at 06.30 and 15.30 hours. The urine was measured by volume and $10 \%$ of that was taken and placed in a separate bottle for each animal and was stored at $4{ }^{\circ} \mathrm{C}$ until future (maximum 24 hours) analysis.

\subsubsection{Chemical analyses}

\subsubsection{Purine estimation}

Purine in yeast RNA was used as a standard. The procedure combines standard literature methods for hydrolysis of nucleotides by perchloric acid followed by precipitation of free purines with silver nitrate to separate the purines from interfering compounds. Acid resolubilized purines in urine were quantified spectrophotometrically at $260 \mathrm{~nm}$ as a yeast RNA equivalent, according to the procedure of Zinn and Owens [67].

The amount of microbial purines absorbed $\left(\mathrm{g} \cdot \mathrm{day}^{-1}\right)$ corresponding to the purine derivatives excreted $\left(\mathrm{g} \cdot \mathrm{day}^{-1}\right)$ was calculated based on the ratio of purines to $\mathrm{N}$ of isolated bacteria [67], and the microbial mass, which was digested and released with the purines, can be obtained with the formula:

$$
Y=[X-(0.0002 E \times 0.12)] \times 0.1489^{-1}
$$

where, $Y$ is the microbial biomass $\left(\mathrm{g} \cdot \mathrm{day}^{-1}\right)$, $X$ is the purine (yeast RNA equivalent) $\mathrm{g} \cdot \mathrm{day}^{-1}$ and 0.1489 is the coefficient for conversion of the purine (yeast RNA equivalent) to microbial mass. This model corrects 
for the contribution of endogenous purine by the component within the parentheses, which is influenced by energy intake $(E)$ as a kJ.day $^{-1}[25]$.

\subsubsection{Determination of rumen enzymes}

\subsubsection{Urease (urea amidohydrolase;} EC 3.5.1.5)

The assay procedure of urease activity was done according to the method of Pathak et al. [50]. The enzyme activity was determined by measuring the amount of ammonia produced during the incubation of the enzyme sample with urea. In this regard, $0.25 \mathrm{~mL}$ sample, $0.25 \mathrm{~mL}$ urea solution (15 mg urea and $8 \mathrm{mg}$ EDTA in $25 \mathrm{~mL}$ phosphate buffer) and $0.5 \mathrm{~mL}$ phosphate buffer were mixed in a tube and incubated for $15 \mathrm{~min}$ at $37^{\circ} \mathrm{C}$. A urea solution and distilled water were used as a control and blank, respectively. After incubation, $5 \mathrm{~mL}$ phenol solution $(1 \mathrm{~g}$ phenol and $5 \mathrm{mg}$ sodium nitropruside in $100 \mathrm{~mL}$ distilled water) and $5 \mathrm{~mL} \mathrm{NaOH}$ solution $(0.5 \mathrm{~g}$ $\mathrm{NaOH}$ and $0.84 \mathrm{~mL}$ sodium hypochlorite in $100 \mathrm{~mL}$ distilled water) was added to the tube and mixed vigorously. The tube was incubated for $15 \mathrm{~min}$ at $37{ }^{\circ} \mathrm{C}$ for color development. Finally the absorbance $(A)$ at $635 \mathrm{~nm}$ was recorded against the blank. A calibration curve (plotting " $A$ " against standard ammonia nitrogen concentration) was used to determine the amount of ammonia nitrogen released in each tube. The enzyme activity was defined as $\mu \mathrm{g}$ ammonia nitrogen released per min per $\mathrm{mL}$ sample.

\subsubsection{Cellulase}

Filter paper activity (Fpase) represents total cellulase activity. The activity of the enzyme was determined colorimeterically by measuring the amount of reducing sugar released during the incubation of the enzyme sample with filter paper (Whatman No. 1) [50]. In this regard, $1 \mathrm{~mL}$ sample, $1 \mathrm{~mL}$ phosphate buffer, and $1 \mathrm{~mL}$ distilled water were mixed in a tube, which contained $50 \mathrm{mg}$ strip Whatman filter paper No. 1 and was incubated for $1 \mathrm{~h}$ at $39^{\circ} \mathrm{C}$. After this time $3 \mathrm{~mL}$ dinitrocalycylic acid (DNS) reagent $(10 \mathrm{~g}$ DNS in $1000 \mathrm{~mL} \mathrm{NaOH}$ solution) was added to the tube and kept in a boiling water bath for $10 \mathrm{~min}$. Then a $1 \mathrm{~mL}$ Rochelle salt solution (40 g Rochelle salt in distilled water to make the volume $100 \mathrm{~mL}$ ) was added to the tube and then cooled under running tap water. Finally, the solution was made up to a volume of $20 \mathrm{~mL}$ with distilled water and the absorbance was recorded (A) at $575 \mathrm{~nm}$ against the blank. The blank was $1 \mathrm{~mL}$ distilled water instead of the sample. A calibration curve (plotting " $A$ " against a standard glucose concentration) was used to determine the amount of glucose released in each tube. Enzyme activity was expressed as $\mu \mathrm{g}$ reducing sugars (glucose) released per $\mathrm{h}$ per $\mathrm{mL}$ sample.

\subsubsection{Protease}

The assay procedure was based on the Blackburn [6] method. A unit of proteolytic activity was defined as the amount of enzyme that would solubilize the equivalent of $1.0 \mu \mathrm{g}$ tyrosine in $1 \mathrm{~min}$.

\subsubsection{Amylase (1,4, $\alpha$-D-glucanohy- drolase, EC 3.2.1.1)}

The $\alpha$-amylase activity was determined by measuring the rate of release of reducing sugars during the incubation of the enzyme with starch. In this regard, $0.25 \mathrm{~mL}$ sample, $0.25 \mathrm{~mL}$ starch solution $(1 \mathrm{~g}$ starch in $100 \mathrm{~mL}$ distilled water) and $0.5 \mathrm{~mL}$ phosphate buffer, were mixed in a tube and incubated for $15 \mathrm{~min}$ at $39{ }^{\circ} \mathrm{C}$. After this time, for color development, a DNS solution was used as described earlier in the Fpase method. Other steps were also the same as when recording glucose concentration in Fpase. Enzyme activity was expressed as $\mu \mathrm{g}$ reducing sugars (glucose) released per min per $\mathrm{mL}$ sample.

\subsubsection{Lipase}

Lipase activity was determined by titration of the fatty acids produced by 
hydrolysis according to the method of Cherry and Crandall, which is explained by Oser [49]. Enzyme samples were incubated with an olive oil emulsion and fatty acids produced were titrated with sodium hydroxide $0.05 \mathrm{~N}$. Units of lipase activity per $\mathrm{mL}$ of enzyme sample were calculated as $\mathrm{mL}$ $\mathrm{NaOH}$ for titration of the fatty acids produced by hydrolysis.

\subsubsection{Statistical analysis}

This experiment was designed as a Latin square with five treatments on five periods. All measurements were performed in at least duplicate. All data from each factor were analyzed with the GLM procedure of SAS [55]. If a significant $(P<0.05)$ main effect was detected, the main effect means were separated by a Duncan test [55]. A correlation among enzymes was determined and correlation coefficients were tested using a $t$-test [55].

\section{RESULTS}

\subsection{Estimation of enzyme activity}

\subsubsection{SRFWP fraction}

The effect of different treatments on enzyme activity in SRFWP is presented in Table II.

All treatments as compared with the control, increased urease activity (Tab. II, $P<0.05)$. There was no significant difference between isoacid, oil and protein treatments $(P>0.05)$. These treatments had $45 \%$, $67 \%$ and $69 \%$ more urease activity than the control, respectively $(P<0.05)$.

A greater cellulase activity was found after the isoacid treatment $(P<0.05)$. A $19 \%$ higher cellulase activity than the control showed that the isoacid is a complex component, which can encourage cellulolytic bacteria. Other treatments did not give any significant difference as compared

Table II. Influence of different treatments on enzyme activities in SRFWPa.

\begin{tabular}{lccccc}
\hline & \multicolumn{5}{c}{ Enzyme activity } \\
\cline { 2 - 6 } Treatment & Urease & Cellulase & Protease & Amylase & Lipase \\
\hline Control & $6.01^{\mathrm{C}}$ & $738.5^{\mathrm{B}}$ & $0.201^{\mathrm{A}}$ & $172.2^{\mathrm{A}}$ & $1.076^{\mathrm{A}}$ \\
& $(3.45)$ & $(81.93)$ & $(0.078)$ & $(45.9)$ & $(0.309)$ \\
Isoacid & $8.71^{\mathrm{B}}$ & $881.3^{\mathrm{A}}$ & $0.186^{\mathrm{A}}$ & $161.6^{\mathrm{A}}$ & $1.165^{\mathrm{A}}$ \\
& $(0.98)$ & $(23.32)$ & $(0.038)$ & $(13.6)$ & $(0.159)$ \\
Oil & $10.02^{\mathrm{B}}$ & $764.4^{\mathrm{B}}$ & $0.152^{\mathrm{A}}$ & $156.5^{\mathrm{A}}$ & $0.988^{\mathrm{AB}}$ \\
& $(2.36)$ & $(24.91)$ & $(0.050)$ & $(25.1)$ & $(0.140)$ \\
Urea & $12.62^{\mathrm{A}} 7$ & $705.3^{\mathrm{B}}$ & $0.161^{\mathrm{A}}$ & $181.6^{\mathrm{A}}$ & $1.135^{\mathrm{A}}$ \\
& $(2.73)$ & $(184.80)$ & $(0.041)$ & $(37.1)$ & $(0.308)$ \\
Protein & $10.14^{\mathrm{B}}$ & $704.2^{\mathrm{B}}$ & $0.162^{\mathrm{A}}$ & $90.1^{\mathrm{B}}$ & $0.816^{\mathrm{B}}$ \\
\multirow{2}{*}{ SE } & $(2.90)$ & $(186.13)$ & $(0.029)$ & $(17.0)$ & $(0.216)$ \\
& 0.37 & 14.23 & 0.007 & 4.67 & 0.29 \\
\hline
\end{tabular}

Units of enzyme activity are: urease $\left(\mu \mathrm{g}\right.$ ammonia $\left.\mathrm{N} \cdot \mathrm{min}^{-1} \cdot \mathrm{mL}^{-1}\right)$, cellulase $\left(\mu \mathrm{g} \mathrm{gluc} \cdot \mathrm{h}^{-1} \cdot \mathrm{mL}^{-1}\right)$, protease (Unit $\left.\cdot \mathrm{mL}^{-1}\right)$, amylase $\left(\mu \mathrm{g}\right.$ gluc $\left.\cdot \mathrm{min}^{-1} \cdot \mathrm{mL}^{-1}\right)$, lipase $\left(\right.$ Unit $\left.\cdot \mathrm{mL}^{-1}\right)$.

${ }^{\text {a }}$ Strained rumen fluid without protozoa.

${ }^{\mathrm{b}}$ Means (standard deviation).

SE: Standard Error.

Means with the same letter in each column are not significantly different $(P<0.05)$. 
with the control diet. Also no difference was detected statistically between treatments for protease activities (Tab. II, $P>0.05$ ).

A significant difference was observed between urea and protein diets for amylolytic activity $(P<0.05)$. This result showed that the nitrogen concentration in the diet did not effect amylolytic activity, because both the urea and protein diet had the same nitrogen content.

The lowest value of lipolytic activity belonged to the protein treatment $(P<0.05)$ and other treatments did not show any significant difference $(P>0.05)$. Nitrogen in the form of the protein diet, showed a negative effect (a $24 \%$ lower lipase activity than the control).

\subsubsection{CFRF fraction}

The effects of different treatments on enzyme activity in a CFRF are presented in Table III. Protein and urea treatments, which have $5 \%$ more nitrogen, than the control showed 2.36 and 2.03 times more urease activity than the control, respectively $(P<0.05)$. Oil treatment and the isoacid diet showed no significant activity $(P>0.05)$ as compared to the control. Substrate availability in the form of urea or protein has this potential, which encourages ureolytic bacteria.

Generally, cellulase activity in CFRF is about $30 \%$ of the activity in SRFWP. Except for the control, other treatments had more or less the same cellulase activities. An isoacid treatment as an important factor for the incitement of cellulolytic bacteria showed $38.2 \%$ more activity compared with the control. When protein and urea were used as a source of $\mathrm{N}$, about $50 \%$ more activity resulted. Addition of protein or urea stimulated the cellulolytic activity. This could mean that the control diet was short in $\mathrm{N}(12 \%$ in $\mathrm{CP}$ content vs. $17 \%$ in $\mathrm{N}$

Table III. Influence of different treatments on enzyme activities in CFRFa.

\begin{tabular}{lccccc}
\hline & \multicolumn{5}{c}{ Enzyme activity } \\
\cline { 2 - 6 } Treatment & Urease & Cellulase & Protease & Amylase & Lipase \\
\hline Control & $7.03^{\mathrm{B}}$ & $162.2^{\mathrm{B}}$ & $0.090^{\mathrm{B}}$ & $60.05^{\mathrm{A}}$ & $0.339^{\mathrm{AB}}$ \\
& $(3.49)$ & $(33.70)$ & $(0.027)$ & $(10.96)$ & $(0.080)$ \\
Isoacid & $9.02^{\mathrm{B}}$ & $224.2^{\mathrm{A}}$ & $0.085^{\mathrm{B}}$ & $63.11^{\mathrm{A}}$ & $0.141^{\mathrm{D}}$ \\
& $(1.33)$ & $(21.54)$ & $(0.014)$ & $(7.12)$ & $(0.043)$ \\
Oil & $9.43^{\mathrm{B}}$ & $223.3^{\mathrm{A}}$ & $0.074^{\mathrm{B}}$ & $36.64^{\mathrm{B}}$ & $0.368^{\mathrm{A}}$ \\
& $(3.47)$ & $(64.54)$ & $(0.015)$ & $(1.07)$ & $(0.089)$ \\
Urea & $14.29^{\mathrm{A}}$ & $244.3^{\mathrm{A}}$ & $0.077^{\mathrm{B}}$ & $61.07^{\mathrm{A}}$ & $0.210^{\mathrm{DC}}$ \\
\multirow{2}{*}{ Protein } & $(6.86)$ & $(71.84)$ & $(0.015)$ & $(10.89)$ & $(0.044)$ \\
& $16.60^{\mathrm{A}}$ & $249.1^{\mathrm{A}}$ & $0.164^{\mathrm{A}}$ & $44.28^{\mathrm{B}}$ & $0.266^{\mathrm{BC}}$ \\
SE & $(5.44)$ & $(59.83)$ & $(0.043)$ & $(24.89)$ & $(0.247)$ \\
& 0.45 & 6.29 & 0.003 & 1.97 & 0.014 \\
\hline
\end{tabular}

Units of enzyme activity are: urease $\left(\mu \mathrm{g}\right.$ ammonia $\left.\mathrm{N} \cdot \mathrm{min}^{-1} \cdot \mathrm{mL}^{-1}\right)$, cellulase $\left(\mu \mathrm{g} \mathrm{gluc} \cdot \mathrm{h}^{-1} \cdot \mathrm{mL}^{-1}\right)$, protease (Unit. $\left.\mathrm{mL}^{-1}\right)$, amylase $\left(\mu \mathrm{g}\right.$ gluc $\left.\cdot \mathrm{min}^{-1} \cdot \mathrm{mL}^{-1}\right)$, lipase $\left(\right.$ Unit $\left.\cdot \mathrm{mL}^{-1}\right)$.

${ }^{\text {a }}$ Cell free rumen fluid.

b Means (standard deviation).

SE: Standard Error.

Means with the same letter in each column are not significantly different $(P<0.05)$. 
supplemented diets). Fatty acids or other components, which derived from the oil diet, could also be a factor for heartening of cellulolytic bacteria. There was a significant difference $(P<0.05)$ between oil treatment and the control.

The protein diet showed the highest value of proteolytic activity as compared with other treatments $(P<0.05)$. The groundnut cake had 5\% more nitrogen than the control therefore explaining its $82.3 \%$ higher proteolytic activity than the control $(P>$ $0.05)$. Nitrogen in the form of urea did not affect proteolytic activity. Also an effect of growth promotion of the isoacid on cellulolytic bacteria was not seen in the proteolytic bacteria, because between the isoacid diet and the control, there was no significant difference $(P>0.05)$.

In Table III, the highest amylolytic activity is for isoacid and the lowest value is for the oil treatment. The oil treatment caused about a $40 \%$ depression in amylolytic bacteria $(P<0.05)$. Crude protein in the form of the groundnut cake, also reduced amylase activity as much as $26.3 \%$ compared with the control $(P<0.05)$, but nitrogen in the form of urea did not change amylolytic activity compared with the control $(P>0.05)$.

Lipolytic activity in CFRF is reflected by soluble lipase in the rumen liquor, since lipase is accompanied with the cell, the lipolytic activity in CFRF is $75 \%$ lower than SRFWP. Even so, oil treatment showed the highest value and the isoacid treatment showed the lowest value for lipolytic activity $(P<0.05)$. These results showed that the isoacid could not act as a growth promoter for lipolytic bacteria $(P<0.05)$. Nitrogen in both forms (urea or protein) reduced lipase activity $(P<0.05)$.

\subsubsection{EABC fraction}

The protein treatment had the highest value of ureolytic activity and the lowest value belonged to the isoacid treatment. A significant difference was shown between the lowest and highest values $(P<0.05)$. The effect of nitrogen on ureolytic activity was clear, just as protein and urea treatments had $55 \%(P<0.05)$ and $25 \%$ more activity rather than the control, respectively.

It was shown that the highest cellulase activity belonged to the protein diet and the lowest value was related to the urea treatment. The differences between the lowest and highest values were significant $(P<0.05)$, and showed that nitrogen alone was not enough for the incitement of the cellulolytic activity in bacteria and that this type of bacteria needs $\mathrm{N}$ in the form of a protein supply. Isoacid, oil and protein treatments showed respectively $39 \%$, $53.3 \%$ and $75 \%$ more activity than the control $(P<0.05)$. Generally proteolytic activity in EABC was 2.3 times more than this activity in CFRF (Tabs. III and IV). The difference between the highest and lowest values within the treatments was $20.5 \%$, but this amount was not significant $(P>0.05)$.

Nitrogen treatment in the form of protein showed superiority for the isoacid diet, for amylolytic activity $(P<0.05)$, but urea did not show the same result.

\subsection{Correlation between enzyme activities}

All data from the five treatments were pooled for each fraction and correlation coefficients with levels of significant probability related to these data are also shown in Tables V, VI and VII.

With the exception of the correlation coefficient between protease with amylase and lipase, no significant correlation was observed throughout the SRFWP fraction (Tab. V, $P>0.05$ ). However, between amylase and cellulase activities a moderate correlation was observed, but weak probability $(P=0.07)$ cannot explain the close relationship between the two enzymes.

In the CFRF fraction, six negative correlation coefficients were found (Tab. VI). 
Among them, only the correlation coefficient for amylase and urease was significant $(P<0.05)$ and the others were non significant $(P>0.05)$. A positive significant correlation was observed between amylase and lipase $(P<0.05)$ and urease and protease $(P<0.01)$. In this fraction other correlations were weak and non-significant.

The correlation coefficients between lipase and other enzymes were not significant

Table IV. Influence of different treatments on enzyme activities in EABC ${ }^{\mathrm{a}}$.

\begin{tabular}{lccccc}
\hline \multirow{2}{*}{ Treatment } & \multicolumn{5}{c}{ Enzyme activity } \\
\cline { 2 - 6 } Control & Urease & Cellulase & Protease & Amylase & Lipase \\
& $9.24^{\mathrm{BC}}$ & $405.3^{\mathrm{B}}$ & $0.220^{\mathrm{A}}$ & $208.7^{\mathrm{AB}}$ & $1.225^{\mathrm{A}}$ \\
Isoacid & $(2.149)$ & $(44.19)$ & $(0.046)$ & $(97.0)$ & $(0.803)$ \\
& $5.03^{\mathrm{C}}$ & $562.7^{\mathrm{A}}$ & $0.204^{\mathrm{A}}$ & $102.4^{\mathrm{B}}$ & $1.350^{\mathrm{A}}$ \\
Oil & $(1.744)$ & $(74.19)$ & $(0.092)$ & $(48.8)$ & $(0.689)$ \\
& $10.66^{\mathrm{AB}}$ & $621.1^{\mathrm{A}}$ & $0.233^{\mathrm{A}}$ & $194.7^{\mathrm{AB}}$ & $1.963^{\mathrm{A}}$ \\
Urea & $(4.719)$ & $(145.38)$ & $(0.067)$ & $(127.2)$ & $(0.782)$ \\
& $11.50^{\mathrm{AB}}$ & $368.5^{\mathrm{B}}$ & $0.216^{\mathrm{A}}$ & $244.1^{\mathrm{AB}}$ & $1.680^{\mathrm{A}}$ \\
Protein & $(5.109)$ & $(82.84)$ & $(0.051)$ & $(115.7)$ & $(0.526)$ \\
& $14.30^{\mathrm{A}}$ & $706.2^{\mathrm{A}}$ & $0.245^{\mathrm{A}}$ & $290.1^{\mathrm{A}}$ & $1.581^{\mathrm{A}}$ \\
SE & $(2.350)$ & $(96.95)$ & $(0.082)$ & $(19.0)$ & $(0.561)$ \\
& 0.60 & 21.13 & 0.007 & 19.62 & 0.11 \\
\hline
\end{tabular}

Units of enzyme activity are: urease $\left(\mu \mathrm{g}\right.$ ammonia $\left.\mathrm{N} \cdot \mathrm{min}^{-1} \cdot \mathrm{mL}^{-1}\right)$, cellulase $\left(\mu \mathrm{g} \mathrm{gluc} \cdot \mathrm{h}^{-1} \cdot \mathrm{mL}^{-1}\right)$, protease (Unit. $\left.\mathrm{mL}^{-1}\right)$, amylase ( $\mu \mathrm{g}$ gluc. $\left.\mathrm{min}^{-1} \cdot \mathrm{mL}^{-1}\right)$, lipase $\left(\right.$ Unit.mL $\left.{ }^{-1}\right)$.

${ }^{a}$ Enzyme associated with bacteria cell.

b Means (standard deviation).

SE: Standard Error.

Means with the same letter in each column are not significantly different $(P<0.05)$.

Table V. Correlation coefficients between enzyme activities in data from the SRFWP fraction.

\begin{tabular}{lccccc}
\hline Enzyme & Urease & Cellulase & Protease & Amylase & Lipase \\
\hline Urease & $1.00000^{\mathrm{a}}$ & 0.10619 & 0.09959 & 0.12395 & 0.15172 \\
& $\left(0.0000^{\mathrm{b}}\right)$ & $(0.6469)$ & $(0.6676)$ & $(0.5925)$ & $(0.5115)$ \\
Cellulase & & 1.00000 & 0.31096 & 0.40259 & 0.29104 \\
& & $(0.0000)$ & $(0.1700)$ & $(0.0704)$ & $(0.2006)$ \\
Protease & & 1.00000 & 0.61055 & 0.51696 \\
& & & $(0.0000)$ & $(0.0033)$ & $(0.0164)$ \\
Amylase & & & 1.00000 & 0.33358 \\
& & & & $(0.0000)$ & $(0.1395)$ \\
Lipase & & & & & 1.00000 \\
& & & & & \\
\hline
\end{tabular}

${ }^{a}$ Coefficient of correlation.

${ }^{\mathrm{b}}$ Level of probability. 
Table VI. Correlation coefficients between enzyme activities in data from the CFRF fraction.

\begin{tabular}{|c|c|c|c|c|c|}
\hline \multirow[b]{2}{*}{ Enzyme } & \multicolumn{5}{|c|}{ Enzyme activityb } \\
\hline & Urease & Cellulase & Protease & Amylase & Lipase \\
\hline Urease & $\begin{array}{l}1.00000^{\mathrm{a}} \\
\left(0.0000^{\mathrm{b}}\right)\end{array}$ & $\begin{array}{r}0.09949 \\
(0.6679)\end{array}$ & $\begin{array}{l}0.55138 \\
(0.0096)\end{array}$ & $\begin{array}{c}-0.43168 \\
(0.0507)\end{array}$ & $\begin{array}{c}-0.37703 \\
(0.0920)\end{array}$ \\
\hline Cellulase & & $\begin{array}{l}1.00000 \\
(0.0000)\end{array}$ & $\begin{array}{l}0.15191 \\
(0.5110)\end{array}$ & $\begin{array}{c}-0.01560 \\
(0.9465)\end{array}$ & $\begin{array}{c}-0.11853 \\
(0.6088)\end{array}$ \\
\hline Protease & & & $\begin{array}{r}1.00000 \\
(0.0000)\end{array}$ & $\begin{array}{c}-0.06453 \\
(0.7811)\end{array}$ & $\begin{array}{c}-0.32368 \\
(0.1523)\end{array}$ \\
\hline Amylase & & & & $\begin{array}{r}1.00000 \\
(0.0000)\end{array}$ & $\begin{array}{c}0.47258 \\
(0.0305)\end{array}$ \\
\hline Lipase & & & & & $\begin{array}{l}1.00000 \\
(0.0000)\end{array}$ \\
\hline
\end{tabular}

${ }^{\text {a }}$ Coefficient of correlation.

${ }^{\mathrm{b}}$ Level of probability.

$(P>0.05)$ in the EABC fraction, but there was a moderate to strong positive significant correlation among the other enzymes (Tab. VII, $P<0.01)$.

In the three fractions of the rumen fluid, it was best to use the coefficient of determination $\left(r^{2}\right)$ to explain the degree of association between two variables. In this regard, in the SRFWP fraction, the $r^{2}$ calculated for protease with amylase and lipase are 0.373 and 0.267 , respectively. These amounts signify that $37.3 \%$ and $26.7 \%$ of the total variation in protease activity can be explained by the relationship between protease activity with the amount of amylase and lipase activities, respectively. In this manner,

Table VII. Correlation coefficients between enzyme activities in data from the EABC fraction.

\begin{tabular}{lccccc}
\hline Enzyme & Urease & Cellulase & Protease & Amylase & Lipase \\
\hline Urease & $1.00000^{\mathrm{a}}$ & 0.52633 & 0.78104 & 0.76398 & -0.14197 \\
& $\left(0.0000^{\mathrm{b}}\right)$ & $(0.0142)$ & $(0.0001)$ & $(0.0001)$ & $(0.5393)$ \\
Cellulase & & 1.00000 & 0.66993 & 0.64462 & 0.02990 \\
& & $(0.0000)$ & $(0.0009)$ & $(0.0016)$ & $(0.8976)$ \\
Protease & & 1.00000 & 0.72454 & 0.09343 \\
& & & $(0.0000)$ & $(0.0002)$ & $(0.6871)$ \\
Amylase & & & 1.00000 & 0.13575 \\
& & & & $(0.0000)$ & $(0.5574)$ \\
Lipase & & & & 1.00000 \\
& & & & & $(0.0000)$
\end{tabular}

${ }^{\text {a }}$ Coefficient of correlation.

${ }^{\mathrm{b}}$ Level of probability. 
coefficients of determination for urease with amylase and protease in the CFRF fraction are 0.304 and 0.186 , respectively.

With respect to the significant correlation coefficient between enzyme activities in the EABC fraction (except lipase with other enzymes), this possibly explains the significant overlapping function among enzymes. In this regard, the highest overlapping function was detectable for protease and urease $(61 \%)$ and the lowest value was related to cellulase and urease $(27.7 \%)$.

\subsection{Estimation of microbial growth}

Data related to microbial biomass are presented in Table VIII. Five percent higher nitrogen than the control produced more than $45 \%$ microbial mass as compared to the control. Twenty-five percent microbial mass more than the control showed the best result for the isoacid component, whereas crude protein in the isoacid diet was the same as the control. The oil diet produced $20 \%$ more microbial mass than the control $\operatorname{diet}(P<0.05)$. Microbial mass production per Mcal of metabolizable energy (ME) showed although oil has $12 \%$ more production than the control, but this amount was not significant $(P>0.05)$. In this regard, protein and urea treatments have protected their superiority rather than others. Their production showed a more than $45 \%$ increase, compared with the control. The isoacid treatment also showed $25 \%$ more microbial production per Mcal intake than the control diet. This amount was significant $(P<0.05)$.

\section{DISCUSSION}

\subsection{Enzyme activity}

Considering the nature of the urease enzyme that is produced in bacterial cells and its extracellular action, no clear difference was found among SRFWP, CFRF and EABC fractions (Tabs. II, III and IV). The highest value of ureolytic activity in urea treatment in SRFWP and CFRF showed that the addition of urea could stimulate urease activity, because urea is a substrate for the function of ureolytic bacteria. These results agree with Caffrey et al. [13], who found that ureolytic activity was greater with a urea diet. In the oil and isoacid treatments we could see an intermediate position between the urea treatment and the control in all fractions. Isoacid, as a factor for the growth of bacteria and derivative components from hydrolyzing of oil, also caused encouragement of activity in bacteria. The net result of these activities resulted in an increase in the ureolytic activity in these treatments compared with the control.

The use of isoacids $[10,20,43,60]$ and lipids $[22,33]$ is coupled with microbial growth, which also needs $\mathrm{NH}_{3}$ as a component for protein synthesis. The use of $\mathrm{NH}_{3}$ for microbial synthesis caused the ammonia

Table VIII. Estimation of microbial biomass in different types of treatments.

\begin{tabular}{lcc}
\hline Treatment & \multicolumn{1}{c}{ Microbial biomass $\left(\mathrm{g} \cdot \mathrm{day}^{-1}\right)$} & $\begin{array}{c}\mathrm{Y}_{\mathrm{ME}}^{\mathrm{a}} \\
{\left[\mathrm{g} \cdot \mathrm{ME}^{-1}(\mathrm{Mcal})\right]}\end{array}$ \\
\hline Control & $42.989^{\mathrm{C}}$ & $29.134^{\mathrm{C}}$ \\
Isoacid & $53.983^{\mathrm{B}}$ & $36.584^{\mathrm{B}}$ \\
Oil & $51.573^{\mathrm{B}}$ & $32.800^{\mathrm{BC}}$ \\
Urea & $61.739^{\mathrm{A}}$ & $42.847^{\mathrm{A}}$ \\
Protein & $63.956^{\mathrm{A}}$ & $44.003^{\mathrm{A}}$ \\
\hline
\end{tabular}

\footnotetext{
${ }^{\mathrm{a}} \mathrm{Y}_{\mathrm{ME}}=($ microbial biomass $) \times[\text { Metabolizable energy consumed }(\text { Mcal })]^{-1}$.
} 
concentration in the rumen to decrease. On the contrary, ammonia, the product of urease activity, has been reported to inhibit urease activity of some anaerobic bacteria [24, 36] and there is evidence that another enzyme, glutamine synthetase, can regulate the production of urease in Selenomonas ruminantium [59] because this enzyme is involved in $\mathrm{NH}_{3}$ uptake for bacterial protein synthesis. The activities of both these enzymes could be increased many-fold when ammonia is limiting.

Leatherwood [39] reported that bacterial cellulases are more endocellulolytic than exocellulolytic. Forsberg et al. [21] demonstrated that the cellulase of B. Succinogenes is bound to the outer membrane. This suggests that $B$. Succinogenes must come into physical contact with its substrate in order to hydrolyze it. For these reasons, in EABC the extracted enzymes from bacteria were more active compared to CFRF. However, Forsberg et al. [21] observed significant quantities of cellulase in culture fluid after centrifugation to remove intact cells. Results in CFRF were in agreement with their findings.

Isoacid is an extraordinary factor for cellulolytic bacteria in relation to growth encouragement and cellulase production. Data for this aspect of the isoacid effect which is in agreement with Bryant [11], Dehority and Scott [18]; Gorosito et al. [26], Brondani et al. [10] are shown in Tables II, III and IV.

CFRF and EABC fractions for oil treatment showed more cellulolytic activity than the control $(P<0.05)$. Recent work [22] has shown that glycerol and galactose arising from lipid hydrolysis are fermentable. These products could be motivating factors for growth and enzyme production of bacteria. As found in oil, protein treatment showed higher cellulolytic activity in CFRF and EABC fractions than in the control. Protein, peptide and amino acids derived from solubility and hydrolyzing of groundnut cake enhanced cellulolyic bacteria favoring higher activity. This data is in agreement with Baldwin and Allison [4], who mentioned that this type of protein could be an enhancer for cellulase activity. In this regard, Leatherwood [39] favored the view that the nonhydrolytic protein acts as an affinity factor by aiding the binding of cellulase to cellulose.

Bacteria have been reported to be primarily responsible for the degradation of plant protein, and protozoa were thought to only have a minor role in this metabolic activity [48]. In this regard, Wallace and Cotta [66] reported that the role of protozoa in ruminal protein degradation is mostly related to the degradation of feed particles and bacterial proteins, but their overall effect on protein degradation is still controversial. Most of the protease is cell bound [48, 52]; only a small portion is extracellular [1]. In this regard, protease activities in SRFWP and EABC are higher than in CFRF. Two fractions of SRFWP and EABC have the same activity, which is in agreement with the results of Cotta and Hespell [16]. They reported that both the cell-associated and culture fluid activities have similar properties with respect to temperature stability and optimal pH. No statistical difference was seen in protease activity in all the diets in SRFWP. Blackburn and Hobson [7] also reported that the proteolytic activity of whole rumen fluid of sheep did not depend on the diet of the animals. Present data showed that increasing protein could be an enhancing factor for more production of protease, which has shown its effect in the CFRF fraction. Pollock [51] showed that this protease may be truly extracellular and Blackburn [6] reported that extracellular protease released to the medium is $20 \%$, while Agrawal et al. [1] showed that this amount is $10-15 \%$.

In SRFWP, the protein diet showed half the amylolytic activity of the urea treatment and this difference was significant $(P<0.05)$. The reasons for this were not clear though in the latter case, the protein 
was less water-soluble than the urea source fed for providing available nitrogen. However, Slyter et al. [57] reported that ureafed steers contained a greater concentration of amylolytic bacteria.

Values in CFRF are a reflection of extracellular enzymes. With the exception of urease, other enzymes are mostly cell bound; therefore the net result of this sequence gave lower activity in the CFRF fraction. More than $50 \%$ of amylolytic activity is cell bound in S. bovis, when starch is the substrate [15]; with the help of ultra sonication, the intracellular enzymes are released into the buffer. For this reason, in EABC we can see the highest value for amylolytic activity in a protein diet, which cannot be seen in other fractions. In this manner some proteolytic bacteria such as B. amylophilus and B. ruminicola [29] and S. bovis [64] included in starch hydrolyzing bacterium, and this means that these types of bacteria have both amylolytic and proteolytic activities. These enzymes are released in buffer after sonication.

In SRFWP, except for the protein diet, other treatments have more or less similar lipolytic activities. The reason for lower activities in the protein diet is not completely clear, although this may be due to the adsorption of lipase, or lipid derivation from lipase action by some bacteria or protein molecule; this aspect is however open for more research. Some workers [5, 27] have reported uptake of long chain fatty acids by bacteria. The adsorption was very rapid, taking place within 1 min of the addition of the fatty acid to the bacterial suspension. In the CFRF fraction, because there was no adsorption or binding to bacteria, better lipolytic activity with extracellular origin was observed. The effect of isoacids and urea on the enhancement of lipolytic bacteria for the production of extracellular lipase was negative. This effect in the isoacid treatment may concern more sugar derivation from cellulose material, which is the result of higher cellulolyic activity in this diet.
The observation of Demeyer in the paper of Latham et al. [38] showed that the inclusion of sugar in the diet of a sheep or of glucose in the in vitro incubation of rumen fluid reduces lipolysis.

\subsection{Correlation coefficients between enzymes}

In SRFWP and EABC fractions, the correlation between protease and amylase was significant and positive. A large portion $(30-35 \%)$ of protease activity in the rumen is due to bacterial action [1]. Most of the proteolytic bacteria in the rumen are starch degrading bacteria e.g. Ruminobacter amylophilus [30], and Prevotella ruminicola, $[8,65]$. Depending on the type of fractions, significant coefficients of determination $\left(r^{2}\right)$ have been seen. These values showed a very close cooperative action between proteolytic and amylolytic enzymes under the experimental conditions, or there may be the presence of some species of bacteria with both activities such as Streptococcus bovis, Prevotella ruminicola, and Ruminobacter amylophilus, which were later explained.

In the oil incorporated diet, higher lipase activity was expected. But lipolytic bacterium needs energy and nitrogenous substrate. Protease can provide nitrogenous components from protein substance and amylase can provide substance for energy expenditure of this type of bacteria. For this reason, one may be able to see significant correlations between lipase and both protease and amylase in SRFWP and CFRF fractions, respectively. This aspect appears to be a synergistic relationship between lipolytic bacteria and other protein or starch degrading bacteria e.g. Anaerovibrio lipolytica and Selenomonas ruminantium or/and Streptococcus bovis, and, thus supporting each other in the degradation process.

Cellulase and urease have shown that both enzymes did not have any significant correlation with other enzymes in the 
SRFWP fraction (and with lipase in all fractions). This is in agreement with Kamra and Pathak [37] who reported that important cellulose degrading bacteria are protease negative e.g. Fibrobacter succinogenes, Ruminococcus flavefaciens and R. albus. Also, the strict anaerobic bacteria of rumen origin e.g. Prevotella (Bacteroides), Ruminococcus, Butyrivibrio, Selenomonas etc., have lower urease activities than other species. Furthermore none of the anaerobic proteolytic bacteria isolated by Blackburn and Hobson [7] showed urease activity. The results of this experiment showed that cellulolytic bacteria did not have any significant synergistic relationship with other species, for production of other enzymes.

In samples of CFRF, no microbial cells were present, and thus no cooperative or competitive relationship between bacteria was observed. Therefore, any enzyme activity is related to the latter function of microorganisms and interaction between the enzymes. For this reason there was no significant correlation between protease and amylase which is seen in other fractions.

In samples of EABC, all enzymes associated with the bacterial cell, under the sonication condition are released, which may never have been released under normal conditions in live bacteria. In this fraction, all correlations among enzymes (except lipase) were significant. In this manner, for example amylase has significant overlapping functions with urease, cellulase and protease and vice versa. This possibility may bring-up that some species of bacteria have the potential for production of two or more enzymes at one time. The positive significant correlation supports this hypothesis. Although bacteria have this potential, in practical conditions, these types of relationships have not been seen between enzymes. In this regard, lipolytic bacteria are completely specialized for the production of lipase, since with a higher coefficient correlation between enzyme activity in the EABC fraction as compared with other fractions, no significant correlation could be observed between lipase and other enzymes.

\subsection{Microbial growth}

In ruminant animals, there may be a close relationship between the production of microbial protein in the rumen and excretion of purine derivatives in the urine $[9$, $58,63]$. The results from this experiment (Tab. VIII) showed that oil, isoacid and nitrogen diets, enhanced microbial synthesis $(P<0.05)$. There was more nitrogen in the form of urea and groundnut cake than from the other treatments. These results are in agreement with the report of Stern and Hoover [62]. They indicated that rumen microbial synthesis requires an adequate supply of nitrogen to achieve maximum efficiency. Some workers $[12,31,56]$ reported the effect of nitrogen source in the form of true protein on increasing ruminal protein production. On the contrary to these reports, Lindberg and Jacobsson [40] concluded that the urinary excretion of purine derivatives in ruminants is largely unaffected by moderate changes in energy intake and by large changes in protein intake.

In several studies, the importance of isoacids as a growth stimulant for ruminal microorganisms has been demonstrated [3, $11,41]$. The results of this experiment are in agreement with these reports. Isoacid can be a factor for a $25 \%$ increased production of microbial mass $\left(\mathrm{g} \cdot \mathrm{d}^{-1}\right)$ as compared with the control. Microbial mass $\left(\mathrm{g} \cdot \mathrm{d}^{-1}\right)$ in the oil diet was $20 \%$ higher than in the control. This was in agreement with several studies. Ikwuegbu and Sutton [32] showed that linseed oil in the rumen of sheep is accompanied by decreased ammonia concentration and increased $\mathrm{N}$ flow to the duodenum. Similar changes occur when sheep are fed additional lipids as either corn oil or lecithin [34]. The efficiency of microbial protein synthesis is attributed to the reduction of protozoal numbers in the rumen and less bacterial $\mathrm{N}$ recycling [35]. 


\section{CONCLUSION}

Any attempt to improve ruminant nutrition must consider the fact that any alterations in feed composition will lead to a change in the rumen ecosystem. Isoacid showed an extraordinary factor for cellulolytic bacteria in relation to growth encouragement and cellulase production. Depending upon the type of enzymes in each fraction, a significant coefficient of determination $\left(r^{2}\right)$ was seen. For example, $r^{2}$ between amylase and protease showed a very close cooperative action between proteolytic and amylolytic activity under experimental conditions, or perhaps the presence of some species of bacteria with both activities.

Lipolytic bacteria are completely specialized in the production of lipase, but not the other enzymes, which were studied in this experiment. Our results showed that oil, isoacid and crude protein enhance microbial production and this could change the pattern of enzymes in the rumen of sheep.

\section{REFERENCES}

[1] Agrawal N., Kewalramani N., Kamra D.N., Agarwal D.K., Nath K., Hydrolytic enzymes of buffalo rumen: composition of cell free rumen fluid, bacterial and protozoal fractions, Buffalo J. 7 (1991) 203-207.

[2] Andries J.I., Buysse F.X., De Brabander D.L., Cottyn B.G., Isoacids in Ruminant Nutrition: Their role in ruminal and intermediary metabolism and possible influence on performances, Anim. Feed Sci. Tech. 18 (1987) 169-180.

[3] Argyle J.L., Baldwin R.L., Effects of amino acids and peptides on rumen microbial growth yield, J. Dairy Sci. 72 (1989) 2017.

[4] Baldwin R.L., Allison M.J., Rumen metabolism, J. Anim. Sci. 57 (1983) 461-477.

[5] Banchart D., Legay-Carmier F., Doreau M., Gaillard B., Lipid metabolism of liquid associated and solid-adherent bacteria in rumen contents o dairy cows offered lipid-supplemented diets, Br. J. Nutr. 63 (1990) 563.

[6] Blackburn T.H., Protease production by Bacteroides amylophilus strain H18, J. Gen. Microbiol. 53 (1968) 27-36.
[7] Blackburn T.H., Hobson P.N., Isolation of proteolytic bacteria from the rumen of sheep, J. Gen. Microbiol. 22 (1960) 282-289.

[8] Blackburn T.H., Hobson P.N., Further studies on the isolation of proteolytic bacteria from the sheep rumen, J. Gen. Microbiol. 29 (1962) 69-81.

[9] Blaxter K.L., Martin A.K., The utilization of protein as a source of energy in fattening sheep, Br. J. Nutr. 16 (1962) 397-407.

[10] Brondani A., Towns R., Chou K., Cook R.M., Effects of isoacids, urea, and sulphur on ruminal fermentation in sheep fed high fiber diets, J. Dairy Sci. 74 (1991) 2724-2727.

[11] Bryant M.P., Nutritional requirements of the predominant rumen cellulolytic bacteria, Fed. Proc. 32 (1973) 1809.

[12] Burrough W., Nelson D.K., Mertens D. R., Evaluation of protein nutrition by metabolizable protein and urea fermentation potential, J. Dairy Sci. 58 (1975) 611-620.

[13] Caffrey P.J., Hatfield E.E., Norton H.W., Garrigus U.S., Nitrogen metabolism in the Ovine. Adjustment to a urea-rich diet, J. Anim. Sci. 26 (1967) 595-600.

[14] Considine P.J., Coughlan M.P., Production of carbohydrate-hydrolyzing enzyme blends by solid-state fermentation, in: Coughlan M.P. (Ed.), Enzyme systems for lignocellulose degradation, Elsevier Applied Science, New York (1989) pp. 273-281.

[15] Cotta M.A., Amylolytic activity of selected species of ruminal bacteria, Appl. Environ. Microbiol. 54 (1988) 772-776.

[16] Cotta M.A., Hespell R.B., Proteolytic activity of ruminal bacterium, Butyrivibrio fibrisolvens, Appl. Environ. Microbiol. 52 (1986) 51-58.

[17] Dehority B.A., Microbial interaction in the rumen, Rev. Fac. Agron. (LUZ) 15 (1998) 69-86.

[18] Dehority B.A., Scott H.W., Extent of cellulose and hemicellulose digestion in various forage by pure cultures of rumen bacteria, J. Dairy Sci. 50 (1967) 1136-1141.

[19] Dehority B.A., Orpin C.G., Development of, and natural fluctuation in, rumen microbial population, in: Hobson P.N. (Ed.), The Rumen Microbial Ecosystem, Elsevier Applied Science, London, 1988, p. 151.

[20] Felix A., Cook R.M., Huber J.T., Isoacids and urea as a protein supplement for lactating cows fed corn Silage, J. Dairy Sci. 63 (1980) 1098-1103.

[21] Forsberg C.W.V., Beveridge T.J., Hellstrom A., Cellulase and xylanase release from Bacteroides succinogenes and its importance in the rumen environment, Appl. Environ. Microbiol. 42 (1981) 886-895. 
[22] France J., Siddons R.D., Volatile fatty acid production, in: Forbes J.M., France J. (Eds.), Quantitative Aspects of Ruminant Digestion and Metabolism, C.A.B. International, 1993, pp. 107-121.

[23] Gash B.A., Cellulase production and activity by Trichoderma sp. A-100, J. Appl. Bacteriol. 73 (1992) 79-82.

[24] Gibbons R.J., Doetsch R.N., Physiological study of an obligatory anaerobic ureolytic bacterium, J. Bacteriol. 77 (1959) 417-428.

[25] Giesecke D., Stangassinger M., Tiemeyer W., Nucleic acid digestion and urinary purine metabolites in sheep nourished by intragastric infusions, Can. J. Anim. Sci. 64 (Suppl.) (1984) 144-145.

[26] Gorosito A.R., Russell J.B., Van Soest P.J., Effect of carbon-4 and carbon-5 volatile fatty acids on digestion of plant cell wall in vitro, J. Dairy Sci. 68 (1985) 840-847.

[27] Harfoot C.G., Hazlewood G.P., Lipid metabolism in the rumen, in: Hobson P.H. (Ed.), The Rumen Microbial Ecosystem, Elsevier, Appl. Sci. Publ. Co., Inc., New York, NY, 1988, p. 285.

[28] Hefner D.L., Berger L.L., Fahey G.G. Jr., Branched-chain fatty acid supplementation of corn crop residue diets, J. Anim. Sci. 61 (1985) 1264-1275.

[29] Hobson P.N., Wallace J.R., Microbial ecology and activities in the rumen: part I, Crit. Rev. Microbiol. 9 (1982) 165-225.

[30] Hobson P.N., McDougall E.I., Summers R., The nitrogen sources of Bacteroides amlyophilus, J. Gen. Microbiol. 50 (1968) 124-129.

[31] Hume I.D., Moir R.J., Somers M., Synthesis of microbial protein in the rumen. I. Influence of the level of nitrogen intake, Aust. J. Agric. Res. 21 (1970) 283-289.

[32] Ikwuegbu O.A., Sutton J.D., The effect of varying the amount of linseed oil supplementation on rumen metabolism in sheep, Br. J. Nutr. 48 (1982) 365-370.

[33] Ilian M.A., Razzaque M.A., Salman, A.J., Use of fat in diets of sheep in hot environments. II. Effect on rumen metabolism, Anim. Feed Sci. Tech. 19 (1988) 343-350.

[34] Jenkins T.C., Fotouhi N., Effects of lecithin and corn oil on site of digestion, ruminal fermentation and microbial protein synthesis in sheep, J. Anim. Sci. 68 (1990) 460-469.

[35] Jenkins T.C., Palmquist D.L., Effect of fatty acids or calcium soaps on rumen and total nutrient digestibility of dairy rations, J. Dairy Sci. 67 (1984) 978-987.

[36] John A., lassaacson H.R., Bryant M.P., Isolation and characteristics of a ureolytic strain of Selenomonas ruminantium, J. Dairy Sci. 57 (1974) 1003-1010.

[37] Kamra D.N., Pathak N.N., Nutritional Microbiology of Farm Animals, Vikas Publishing House Pvt. Ltd., Delhi 110032, India, 1996.
[38] Latham M.J., Storry J.E., Sharp M.E., Effect of low-roughage diets on the microflora and lipid metabolism in the rumen, Appl. Microbiol. 24 (1972) 871-877.

[39] Leatherwood J.M., Cellulose degradation by Ruminococcus, Fed. Proc. 32 (1973) 1814-1820.

[40] Lindberg J.E., Jacobsson K.G., Nitrogen and purine metabolism at varying energy and protein supplies in sheep sustained on intragastric infusion, Br. J. Nutr. 64 (1990) 359-370.

[41] Maeng W.J., Baldwin R.L., Factors influencing rumen microbial growth rates and yields: effect of amino acid additions to a purified diet with nitrogen from urea, J. Dairy Sci. 59 (1976) 648-655.

[42] McAllister T.A., Hristov A.N., Beauchemin K.A., Rode L.M., Cheng, K.-J., Enzymes in ruminant diets, in: Bedford M.R., Partridge G.G. (Eds.), Enzymes in Farm Animal Nutrition, CABI Publishing, 2001, pp. 273-278.

[43] Mir P.S., Mir Z., Robertson J.A., Effect of branched-chain amino acids or fatty acids supplementation on in vitro digestibility of barley straw or alfalfa hay, Can. J. Anim. Sci. 66 (1986) 151-156.

[44] Moharrery A., Study of enzymes (urease, cellulase, protease, amylase and lipase) activity in the rumen after incorporating isoacid, oil, urea and protein supplement in the rumen of sheep, Ph.D. thesis, University of Agricultural Sciences, Bangalore, India, 1999.

[45] Moharrery A., Das T.K., Afzali N., Effect of slow freezing on solubility of animal protein, Vol. II, Scientific proceedings, pp. 956-959. Second pan commonwealth veterinary conference. On Animal Health and Production In Rural Areas- The Essential Role of Women at all Levels, 22-27 Feb., 1998, Bangalore, India, 1998.

[46] Morgavi D.P., Newbold C.J., Beever D.E., Wallace R.J., Stability and stabilization of potential feed additive enzymes in rumen fluid, Enzym. Microbiol. Technol. 26 (2000) 171-177.

[47] NRC, Nutrient Requirements of sheep, Sixth revised edition, National Academy Press, Washington, D.C., 1985.

[48] Nugent J.H.A., Mangan J.L., Characteristics of the rumen proteolysis of fraction 1 (18S) leaf protein from lucerne (Medicago sativa $L$ ), Br. J. Nutr. 46 (1981) 39-58.

[49] Oser B.L., Hawk's Physiologyical Chemistry, 14th edition, TATA McGraw-hill Publishing Co. LTD, New Delhi, 1965, p. 1123.

[50] Pathak N.N., Kamra D.N., Jakhmola R.C., Analytical Techniques in Animal Nutrition Research, International Book Distributing Co., India, 1996, p. 201

[51] Pollock Mr, Exoenzymes, in: Gunsalus I.C., Stainer R.Y. (Eds.), The Bacteria, Vol. 4, New York and London, Academic Press Inc, 1962, p. 121. 
[52] Prins R.A., Van Rheenen D.L., Van Klooster A.T., Characterization of microbial proteolytic enzymes in the rumen, Antonie Van Leeuwenhoek 49 (1983) 585-595.

[53] Ranjhan S.K., Animal Nutrition, in: The Tropics, Third revised edition, Vikas Publishing House, PVT, LTD, Delhi-India, 1993, p. 542.

[54] Reid J.T., Urea as a protein replacement for ruminants: A review, J. Dairy Sci. 36 (1953) 955-996.

[55] SAS, SAS user's guide: statistics, SAS Inst., Inc., Cary, N.C., 1996.

[56] Satter L.D., Roffler R.E., Nitrogen requirement and utilization in dairy cattle, J. Dairy Sci. 58 (1975) 1219-1226.

[57] Slyter L.L., Oltigen R.R., Kern D.L., Weaver, J.M., Microbial species including ureolytic bacteria from rumen of cattle fed purified diets, J. Nutr. 94 (1968) 185-192.

[58] Smith R.H., in Digestion and Metabolism in: McDonald J.W., Warner A.C. (Eds.), The Ruminant, Armidal, University of New England Press, 1975.

[59] Smith M.S., Bryant M.P., Introduction to metabolic activities of intestinal bacteria, A.M. J. Chin. Nutr. 32 (1979) 149-159.

[60] Soofi R., Fahey G.C., Berger L.L. Jr., Hingo F.C., Effect of branched chain volatile fatty acids, Trypticase, urea and starch on in vitro dry matter disappearance of soybean stover, J. Dairy Sci. 65 (1982) 1748-1753.

[61] Stack R.J., Hungate R.E., Opsahl W.P., Phenylacetic acid stimulation of cellulose digestion by Ruminococcus albus 8, Appl. Environ. Microbiol. 46 (1983) 539-545.

[62] Stern M.D., Hoover W.H., Methods for determining and factors affecting rumen microbial protein synthesis: A Review, J. Anim. Sci. 49 (1979) 1590-1603.

[63] Topps J.H., Elliott R.C., Relationship between concentration of ruminal nucleic acids and excretion of purine derivatives by sheep, Nature 205 (1965) 498-499.

[64] Wallace R.J., Synergism between different species of proteolytic rumen bacteria, Curr. Microbiol. 12 (1985) 59-64.

[65] Wallace R.J., Brammall M.L., The role of different species of bacteria in the hydrolysis of protein in the rumen, J. Gen. Microbiol. 131 (1985) 821-832.

[66] Wallace R.J., Cotta M.A., Metabolism of nitrogen-containing compounds, in: Hobson P.N. (Ed.), The Rumen Microbial Ecosystem, Elsevier Applied Science, London, 1988, pp. 217-249.

[67] Zinn R.A., Owens F.N., A rapid procedure for purine measurement and its use for estimating net ruminal protein synthesis, Can. J. Anim. Sci. 67 (1986) 157-166. 